\title{
Comparison of Parameters for Programming Adjustable Dental Articulators by Using Wax Eccentric Records and Arcus Digma Device
}

\section{Usporedba parametara za programiranje prilagodljivih dentalnih artikulatora upotrebom voštanih ekscentričnih registrata i uređaja Arcus Digma}

\author{
${ }^{1}$ Graduate student, School of Dental Medicine University of Zagreb, Zagreb, Croatia. \\ Diplomirana studentica Stomatološkog fakulteta Sveučilišta u Zagrebu, Zagreb, Hrvatska. \\ ${ }^{2}$ Department of Removable Prosthodontics, School of Dental Medicine, University of Zagreb, Zagreb, Croatia. \\ Zavod za mobilnu protetiku Stomatološkog fakulteta Sveučilišta u Zagrebu, Zagreb, Hrvatska.
}

\section{Abstract}

Objectives: Programming of joint mechanism/parameters (sagittal condylar inclination and Bennett angle) of adjustable dental articulators is a prerequisite for performing positions and movements of the mandible. The aim of the study was to test significant differences between the two methods (wax eccentric records and Arcus Digma device) of measuring these joint parameters by using three different dental articulators (SAM 3, Protar 7; and Artex CR). Materials and Methods: Thirty asymptomatic younger (age $25.7 \pm 2.9$ years) subjects (dental medicine students) divided by gender, with normal occlusion (Angle class I) participated in the study. After taking anatomical impressions of both dental arches, master casts were made of hard dental plaster for each subject. The values of the left and right sagittal condylar inclination and Bennett angle by the two methods of wax eccentric protrusive and lateral records and Arcus Digma device were measured for the purpose of programming the mentioned joint parameters in three different articulator systems. Results: The average values of the measured parameters of sagittal condylar inclination and Bennett angle of wax eccentric records were higher (ranging from $5^{\circ}$ to $10^{\circ}$ ) in relation to the values measured by Arcus Digma device. Statistically significant differences found between the measured joint parameters $(p<0.025)$ were in fluenced by the articulator system design and measurement methods (t-test for dependent samples and MANOVA). Conclusion: The use of Arcus Digma device should be considered reliable and valid for individualized programming of dental articulators, rather than the use of wax eccentric records.
Received: April 14, 2019

Accepted: June 25, 2019

Address for correspondence Professor Robert Ćelić, PhD University of Zagreb School of Dental Medicine Department of Removable Prosthodontics Ivana Gundulića 5, 10000 Zagreb, Croatia

Tel: 0038514802118

celic@sfzg.hr

Key words

Temporomandibular Joint; Dental occlusion; Dental Articulators

\section{Introduction}

The use of dental articulators in everyday dental practice, especially in prosthodontics, is an inevitable and standard process if morphological and functional aspects of occlusion within the masticatory system need to be examined and/or restored. Therefore, it is necessary for every clinician using dental articulators to know which parameters (values of condylar path inclination and Bennett angle) should be set (programmed) in order to simulate kinetics of the masticatory system. It is a common practice to set the mentioned parameters on adjustable dental articulators based on average values. However, there is also a so-called individualized measuring, which is as its name suggests a more accurate parameter measurement. It is a precondition for reproduction and simulation of the mandibular position and mandibular movements in a dental articulator. For individualized param-
Uvod

Upotreba dentalnih artikulatora u svakodnevnoj stomatološkoj praksi, posebno u protetici, neizbježna je i standardna ako se žele ispitati i/ili obnoviti morfološki i funkcionalni aspekti okluzije unutar žvačnog sustava. Zato je nužno da svaki kliničar koji se koristi dentalnim artikulatorima zna koje parametre (vrijednosti nagiba kondilne staze i Bennettov kut) treba namjestiti (programirati) na toj napravi kako bi se mogla simulirati kinetika žvačnog organa. Može se reći da je ustaljena praksa spomenute parametre namještati na prilagodljivim dentalnim artikulatorima na temelju prosječnih vrijednosti. No postoji i tzv. individualizirano mjerenje koje svojim nazivom upućuje na točnije mjerenje parametara koji su preduvjet za reprodukciju i simulaciju položaja i kretnji donje čeljusti u dentalnom artikulatoru. Za individualizirano mjerenje parametara mogu se koristiti kliničke metode cen- 
eter measuring clinical methods of wax centric/eccentric records and radiographic technique can be used, as well as dry bone samples and various mechanical and electronic (axiographic) devices $(1-9)$.

Sagittal condylar inclination is defined as the angle between the protrusive condylar path and usually the Frankfort horizontal plane or other horizontal reference planes (e.g. Camper's, axial-orbital, etc.). The average programming of sagittal condylar inclination of semiadjustable dental articulator is based on the type of dental occlusion. An individual with normal occlusion (Angle class I) has a sagittal condylar inclination of $30-35^{\circ}$. In dentate subjects with Angle class II, sagittal condylar inclination is higher, and with Angle class III it is lower. However, it should be noted that these angles should be interpreted bearing in mind the fact that we should determine which horizontal plane is referential (e.g. the difference between the Frankfort horizontal plane and Camper's plane is on average $15^{\circ}$ ) for the relation of the discuscondyle complex protrusion path towards articular tubercle $(10$ - 12). In their study, Ćimić et al. (13) measured the average value of the sagittal condylar inclination for fully dentate subjects (Angle class I) of $40^{\circ}$ in relation to the Camper's plane, by using axiographic ultrasonic devices. They concluded that those values were especially important for adjustable articulator systems programmed in relation to the Camper's plane as reference.

Bennett angle is the angle formed between the sagittal plane and the average path of the non-working (orbiting) condyle as viewed in the horizontal plane during lateral mandibular movements (11). Bennett angle comprises two components of the movement: immediate side shift and progressive side shift. Immediate side shift describes the beginning of lateral movement, i.e. non-working condylar movement toward ahead and medial from the position of centric relation, while progressive side shift relates to continuation of lateral movement to its maximum, i.e. to the remaining part of the non-working condyle path during lateral mandibular movement (which is basically the value of Bennett angle). In general, fully adjustable articulator systems have the possibility of setting/programming the mentioned parameters necessary for as accurate as possible simulation of lateral movements in the articulator $(14-17)$.

There are different studies in the scientific literature in which parameters (sagittal condylar path inclination and Bennett angle) of programming adjustable dental articulators are compared by means of wax eccentric protrusive and lateral records, axiographic devices and/or other methods/ instruments $(17$ - 26). Prasad et al. (17) compared the average measured values of condylar inclination using an ultrasonic axiograph (SAM Axiograph) and a wax protrusive eccentric record in order to program two articulator systems (SAM and Artex CR). Statistically significant differences were found between two methods used for sagittal condylar inclination measurements in subjects with normal occlusion (Angle class I). They recommend using fully adjustable articulators during instrumental-functional diagnostics of the masticatory system and prosthetic treatment, thus avoiding errors at the level of occlusion and tooth wear. Proschel et al. tričnih/ekscentričnih voštanih registrata, radiografske tehnike, uzorci suhe kosti te različite mehaničke i elektroničke (aksiografske) naprave $(1-9)$.

Kondilni (sagitalni) nagib staze definira se kao kut između protruzijske putanje kondila i obično frankfurtske horizontale ili drugih referentnih horizontalnih ravnina (npr., Camperove, osno-orbitalne, itd.). Prosječno programiranje kondilnog nagiba staze temelji se na vrsti okluzije pojedinca, pa tako osobi s Angleovom klasom I (normookluzijom) sagitalni nagib kondila iznosi od 30 do $35^{\circ}$. Kod ozubljenih ispitanika Angleove klase II sagitalni nagib kondila raste, a u slučaju Angleove klase III pada. No treba istaknuti da te kutove treba interpretirati kada se zna prema kojoj se referentnoj horizontalnoj ravnini (npr. razlika između frankfurtske horizontalne i Camperove ravnine prosječno je $15^{\circ}$ ) odnosi protruzijska putanja kompleksa kondil-diskus prema zglobnoj kvržici $(10$ - 12). U istraživanju Ćimića i suradnika (13), korištenjem ultrazvučnog aksiografskog uređaja, izmjerena je prosječna vrijednost sagitalnog kondilnog nagiba za potpuno ozubljene ispitanike (Angleova klasa I) od $40^{\circ}$ u odnosu prema Camperovoj ravnini. Zaključuju da je to posebno važno za prilagodljive artikulatorske sustave koji se programiraju u odnosu prema referentnoj Camperovoj ravnini.

Bennettov kut jest kut formiran između sagitalne ravnine i prosječne putanje neradnog (orbitirajućeg) kondila, promatrano u horizontalnoj ravnini tijekom lateralne kretnje donje čeljusti (11). Bennettov kut sastoji se od dviju komponentikretnji - neposrednog pomaka u stranu (immediate side shi$\mathrm{ft}$ ) i produženog pomaka u stranu (progressive side shift). Neposredni pomak u stranu opisuje početak lateralne kretnje, odnosno kretnju neradnog kondila prema ravno i medijalno iz položaja centrične relacije, a produženi pomak u stranu odnosi se na nastavak lateralne kretnje do njezina maksimuma, odnosno na preostali dio putanje neradnoga kondila tijekom lateralne kretnje donje čeljusti (što je u osnovi vrijednost Bennettova kuta). Općenito, potpuno prilagodljivim artikulatorskim sustavima mogu se namjestiti/programirati ti parametri nužni za što preciznije simuliranje lateralnih kretnji u artikulatoru $(14-17)$.

Postoje različite studije u znanstvenoj literaturi u kojima se uspoređuju parametri (sagitalni nagib kondilne staze i Bennettov kut) programiranja prilagodljivih dentalnih artikulatora uporabom metoda voštanih ekscentričnih protruzivnih i lateralnih registrata i aksiografskih naprava $\mathrm{i} / \mathrm{ili}$ drugih metoda/instrumenata $(17$ - 26). Prasad i suradnici (17) uspoređivali su prosječne izmjerene vrijednosti kondilarnog nagiba upotrebom ultrazvučnog aksiografa (SAM Axiograph) i protruzijskog ekscentričnog voštanog registrata u svrhu programiranja dvaju artikulatorskih sustava (SAM i Artex CR). Pronašli su statistički značajne razlike između dviju korištenih metoda mjerenja sagitalnoga kondilnog nagiba kod ispitanika s normalnom okluzijom (Angleova klasa I). Preporučuju primjenu potpuno prilagodljivih artikulatora tijekom instrumentalno-funkcijske dijagnostike žvačnog sustava i provedbe protetičke terapije, jer se tako izbjegavaju pogreške na razini okluzije zuba i trošenje. Na istom su tragu sa zaključcima Proschel i suradnici (18) koji u svojoj studiji promiču upotrebu dentalnih artikulatora i njihovo individualno programira- 
(18) made similar conclusions by promoting the use of dental articulators and their individual programming. Fanucci et al. (19) measured Bennett angles and programmed an adjustable dental articulator by using wax eccentric lateral records and TMJ scans obtained by computerized tomography. They found matching Bennett angle values between the two measuring methods, which makes both methods reliable in clinical conditions.

The purpose of this study was to determine whether there were differences between the values of individualized measuring of the left and right condylar path inclination, and left and right Bennett angle measured using wax eccentric records and Arcus Digma device in order to program various adjustable articulator systems (SAM 3, Protar 7 and Artex $\mathrm{CR})$. The working hypothesis was that there would be no difference in the measured values of the parameters necessary for programming of adjustable dental articulators by using two methods in the examined sample.

\section{Material and Methods}

The study included 30 asymptomatic subjects (dental medicine students) divided by gender, with normal occlusal relationship (Angle class I), who had not undergone any orthodontic treatment and with no evidence of clinical signs and symptoms of temporomandibular disorders. An alginate impression of the upper and lower dental arch was taken for each subject (Aroma Fine Plus, GC, Tokyo, Japan) in order to make master casts out of hard dental stone (type IV) (Alpenrock, AmannGirrbach Koblach, Austria). Hard (pink) wax plates (Pinnacle, Dentsply Hanau, Germany) were used for making centric records, protrusive records, and left and right laterotrusive records. A centric wax record was used for precise mounting of master casts onto adjustable dental articulators, whereas protrusive and laterotrusive wax records were used for setting values and adjusting the right and left condylar path inclination and left and right Bennett angle. Three adjustable articulator systems were used in this study: SAM 3 (SAM, SAM Präzisionstechnik Gauting, Germany), Protar 7 (Protar, Kavo Biberach, Germany) and Artex CR (Artex, AmannGirrbach Koblach, Austria) (Figure 1).

Centric/eccentric record bases were adjusted to the occlusal surfaces of upper teeth on the upper master cast. The procedure of taking individual records was performed in each subject's mouth in the course of mandibular guidance into centric relation (bimanual manipulation technique), into protrusive position (tete-a-tete) and left and right laterotrusive position (canine guidance). Firstly, an average hinge axis transfer was performed, i.e. transfer of the distance between the upper dental arch and the hinge axis by means of standard (anatomic) face bow, as well as mounting of the upper cast into the upper articulator part. This was followed by the placement of the centric record on the upper dental arch, attachment of the lower master cast and mounting of the cast into the lower articulator part. Afterwards, wax eccentric records (protrusive, left and right laterotrusive records) were placed between dental arches of master casts onto the dental articulator (SAM 3, Protar 7, and Artex CR) in order to ad- nje. Fanucci i suradnici (19) izmjerili su Bennettove kutove i programirali prilagodljivi dentalni artikulator upotrebom voštanih ekscentričnih lateralnih registrata i skenera čeljusnih zglobova dobivenih kompjutoriziranom tomografijom. Pronašli su podudaranje u vrijednostima Bennettova kuta između dviju korištenih metoda mjerenja, što obje metode čini pouzdanima u kliničkim uvjetima.

Svrha ovog istraživanja bit će ustanoviti postoje li razlike između vrijednosti individualiziranog mjerenja lijevoga i desnoga nagiba kondilne staze, lijevoga i desnoga Bennetova kuta izmjerene s pomoću centričnih/ekscentričnih voštanih registrata te uređaja Arcus Digma u svrhu programiranja različitih prilagodljivih artikulatorskih sustava (SAM 3, Protar 7 i Artex CR).

Radna hipoteza istraživanja jest da neće biti razlika u izmjerenim vrijednostima parametara nužnih za programiranje prilagodljivih dentalnih artikulatora korištenjem dviju metoda $u$ ispitivanom uzorku.

\section{Materijal i metode istraživanja}

$\mathrm{U}$ istraživanju je sudjelovalo 30 asimptomatskih ispitanika (studenata dentalne medicine) podijeljenih prema spolu, s normalnim okluzijskim odnosom (Angleova klasa I) koji nisu bili podvrgnuti ortodontskom liječenju te kod kojih nisu zabilježeni klinički znakovi i simptomi temporomandibularnog poremećaja. Svakomu je uzet alginatni otisak (Aroma Fine Plus, GC Tokio, Japan) gornjega i donjega zubnog luka zbog izrade radnih modela u tvrdoj sadri (tip IV) (Alpenrock, AmannGirrbach Koblach, Austrija). Ploče tvrdog (ružičastog) voska (Pinnacle, Dentsply Hanau, Njemačka) upotrijebile su se za izradu centričnih registrata, protruzijskih registrata te lijevoga i desnoga laterotruzijskih registrata. Centrični voštani registrat služi za točno postavljanje radnih modela u prilagodljivi dentalni artikulator, a protruzijski i laterotruzijski voštani registrati služe za određivanje vrijednosti i podešavanje desnoga i lijevoga nagiba kondilne staze te lijevoga i desnoga Bennettova kuta. U ovom istraživanju primijenila su se tri prilagodljiva artikulatorska sustava - SAM 3 (SAM, SAM Präzisionstechnik Gauting, Njemačka), Protar 7, (Protar, Kavo Biberach, Njemačka) i Artex CR CR, (Artex CR, Amann Girrbach Koblach, Austrija) (slika 1.).

Baze centričnih/ekscentričnih registrata prilagodile su se prema okluzijskim plohama gornjih zuba na gornjem radnom modelu. Sam postupak uzimanja pojedinog registrata obavljao se u ustima svakog ispitanika vođenjem donje čeljusti u položaj centrične relacije (tehnika bimanulne manipulacije), u protruzijski položaj (tete-a-tete) te lijevi i desni laterotruzijski zubni položaj (vođenje očnjakom). Najprije se proveo prijenos prosječne šarnirske osi, odnosno prijenos udaljenosti gornjega zubnog luka prema toj osi s pomoću običnog (anatomskog) obraznog luka i ugipsavanje gornjeg modela u gornji dio artikulatora. Slijedilo je postavljanje centričnog registrata na gornji zubni luk, pripojenje donjega radnog modela i njegovo ugipsavanje u donji dio artikulatora. Nakon toga namješteni su ekscentrični voštani registrati (protruzijski, lijevi i desni laterotruzijski registrati) između zubnih lukova radnih modela u dentalni artikulator (SAM 3, Protar 7 i Ar- 

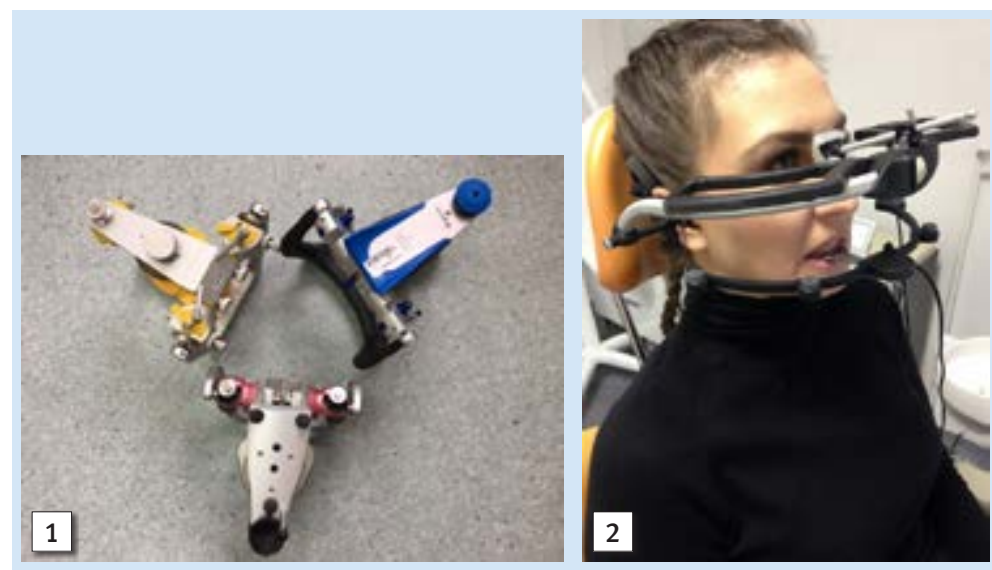

Figure 1 Adjustable articulator systems used in this study (SAM 3, Artex CR, and Protar 7).

Slika 1. Prilagodljivi artikulatorski sustavi korišteni u ovom istraživanju (SAM 3, Protar 7 i Artex CR)

Figure 2 Kinematic face bow with paraocclusal tray of Arcus Digma system for mandibular movements recording.

Slika 2. Kinematski obrazni luk s paraokluzijskom žlicom sustava Arcus Digma za snimanje kretnji donje čeljusti

just and register values of the right and left condylar path inclination (protrusive record), and left and right Bennett angle (right and left laterotrusive records), on the joint mechanism of the dental articulator (1).

Apart from this measurement, the same parameters were measured for each subject by means of an ultrasonic axiograph - Arcus Digma device (Arcus Digma II, Kavo, Biberach, Germany) (21). Arcus Digma is an electronic device for recording mandibular movements, which is based on threedimensional ultrasonic measurement. The device consists of the upper and lower arch. The lower arch of the device is fixed to the lower dental arch by means of paraocclusal tray and carries ultrasonic impulse emitters. The upper arch (face bow) has four pairs of ultrasonic impulse sensors. The device measures time discrepancies of emitted and registered ultrasonic impulses. Depending on time difference of ultrasonic intervals, based on the concept of six degrees of freedom, the software calculates the spatial position of the condyle, as well as of the sagittal incisal point or selected occlusal feature. In other words, the device measures the patient's individual mandibular movements, which are then processed by the software in order to obtain mathematical values (graphical and numerical) of these movements. This device has a wide application. It can be used in the field of instrumental functional diagnostics and accurate application of adjustable articulator systems in different groups of patients, such as patients with clinical signs and symptoms of temporomandibular disorders, prosthetic patients, orthodontic patients, etc. This device provides the information necessary for individual programming of articulators that would e.g. enable design and functional prosthetic restorations in prosthetic patients. According to its software features, it is not intended for only one articulator system (Protar), but the data can be obtained also for other systems (SAM, Panadent, Artex CR, Referenz SL, Money Mark II, Stratos 300). The values of the right and left condylar path inclination and right and left Bennett angle for SAM 3, Protar 7 and Artex CR dental articulators were measured in this study.

The measurement process started with placing the kinematic face and paraocclusal tray on the face of the subject (Figure 2). The paraocclusal tray adjustment was performed on the existing lower master casts made of dental stone (used in the first method of wax records), by using light cured res- tex CR) kako bi se na zglobnom mehanizmu dentalnog artikulatora podesile i očitale vrijednosti desnoga i lijevoga nagiba kondilne staze (protruzijski registrat) te lijevoga i desnoga Bennettova kuta (desni i lijevi laterotruzijski registrat) (1).

Uz to mjerenje, obavilo se mjerenje istih parametara kod svakog ispitanika s pomoću ultrazvučnog aksiografa - uređaja Arcus Digma (Arcus Digma II, Kavo, Biberach, Njemačka) (21). Arcus Digma je elektronički uređaj za bilježenje kretnji donje čeljusti koji se temelji na trodimenzionalnom ultrazvučnom mjerenju. Uređaj se sastoji od gornjega i donjega luka. Donji luk se pričvršćuje na donji zubni niz paraokluzijskom žlicom te na sebi ima emitere ultrazvučnih impulsa. Gornji luk (obrazni luk) ima četiri para senzora ultrazvučnih impulsa. Uređaj mjeri vremenska odstupanja emitiranih i registriranih ultrazvučnih impulsa. Ovisno o vremenskoj razlici ultrazvučnih intervala, na temelju koncepta šest stupnjeva slobode, softverski uređaj izračunava prostorni položaj kondila, sagitalne incizalne točke ili odabranu odrednicu okluzije. Drugim riječima, uređaj mjeri individualne kretnje donje čeljusti pacijenta koje se zatim softverski obrađuju da bi se dobile matematičke vrijednosti (grafičke i numeričke) tih istih kretnji. Područje primjene tog uređaja je široko. Može se koristiti u polju instrumentalno funkcijske dijagnostike i točnije primjene prilagodljivih artikulatorskih sustava u različitim skupinama pacijenata, poput onih $s$ kliničkim znakovima i simptomima temporomandibularnih poremećaja, zatim protetičkih i ortodontskih pacijenata, itd. Taj uređaj daje podatke nužne za individualno programiranje artikulatora koji će, npr. za protetičke pacijente, omogućiti oblikovanje i izradu funkcijskih protetičkih radova. Softverska svojstva te naprave takva su da nije namijenjena samo za jedan artikulatorski sustav (Protar), nego se podatci mogu dobiti i za druge sustave (SAM, Panadent, Artex CR, Referenz SL, Denar Mark II, Stratos 300). U ovom istraživanju mjerile su se vrijednosti desnoga i lijevoga nagiba kondilne staze te desnoga i lijevoga Bennettova kuta za dentalne artikulatore SAM 3, Protar 7 i Artex CR.

Postupak mjerenja uključivao je postavljanje kinematskog obraznog luka fiksiranog u vanjske slušne hodnike i korijen nosa te prilagođenu paraokluzijsku žlicu na donjem zubnom luku (slika 2.). Prilagodba paraokluzijske žlice obavljena je na postojećim donjim radnim sadrenim modelima (korištenima kod prve metode voštanih registrata) upotrebom svjetlosno- 
in (Unitray, Polident, Volčja Draga, Slovenia). Each subject was sitting comfortably in a chair (upright posture) as the paraocclusal tray was attached to the lower dental arch using temporary restorative resin (Structur, Voco, Cuxhaven, Germany). It was important to assure for the paraocclusal tray to be firmly attached to the lower dental arch and not to be in contact with the upper teeth in either maximum intercuspation or lateral mandibular movements. The measurements were carried out in the module "Articulator" of Arcus Digma device, with the settings set to individualization of SAM 3, Protar 7 and Artex CR articulator for each individual subject. All measurements were performed according to the manufacturer's instructions for use (average hinge axis situated $10.33 \mathrm{~mm}$ in front of the tragus medialis point and 3.66 $\mathrm{mm}$ above the line connecting tragus medialis and infraorbital point). Each subject performed three protrusive movements, three left laterotrusive movements and three right laterotrusive movements. The Arcus Digma software calculated the average value of the measured parameters (condylar path inclination angle, Bennett angle) for individualized setting of the selected dental articulators for each subject in this study $(22,23)$.

\section{Results}

The study included a total of 30 asymptomatic subjects divided by gender ( 15 females and 15 males) with normal occlusion (Angle Class I) and with no clinical signs and symptoms of temporomandibular disorders. The subjects were aged between 20 and 34 years $(25.7 \pm 2.9$ years). Table 1 shows descriptive characteristics of the examined variables (values of the left and right condylar inclination measured by performing protrusive mandibular movement and of the left and right Bennett angle measured by performing right and left lateral mandibular movement) using two methods (wax centric/eccentric records and Arcus Digma device) for programming three adjustable articulator systems (SAM 3, Protar and Artex CR). The average values of the measured parameters where wax eccentric records were used showed higher values (ranging from $5^{\circ}$ to $10^{\circ}$ ) in relation to the values measured by Arcus Digma device.

The Kolmogorov-Smirnov test showed normal distribution for all variables; hence in further procedures methods of parametric statistical analysis were applied. All variables were tested by Student's t-test for independent samples, with respect to gender. No statistically significant differences for any tested variable were found according to gender $(p>0.05)$ (Table 2).

T-test for dependent samples checked pairs of variables that were identical according to the movement (measured angle of the left and right condylar path inclination and Bennett angles) and within one type of articulator (SAM 3, Pro$\operatorname{tar} 7$ and Artex CR), with respect to the method applied (wax eccentric records and Arcus Digma). Table 3 shows statistically significant differences at the level of $p<0.05$ for the most of the tested variables, except for the variable pair 9 and 10 (left and right condylar path inclination (protrusive mandibular movement) for Artex CR articulator). The differences polimerizirajućeg akrilata (Unitray, Polident, Volčja Draga, Slovenija). Svaki ispitanik sjedio je udobno u stolcu (uspravan položaj). Paraokluzijska žlica pričvrstila se na donji zubni niz uporabom akrilata za izradu privremenih nadomjestaka (Structur, Voco, Cuxhaven, Njemačka). Pazilo se da je čvrsto vezana na donji zubni niz te da ne bude u doticaju s gornjim zubima u maksimalnoj interkuspidaciji ni u lateralnim kretnjama donje čeljusti. Mjerenja su obavljena u modulu Articulator uređaja Arcus Digma, a postavke namještene na individualizaciju artikulatora SAM 3, Protar 7 i Artex CR za svakog ispitanika. Sva mjerenja obavljena su prema uputama proizvođača (prosječna šarnirska os nalazi se $10,33 \mathrm{~mm}$ ispred točke tragus medialis i 3,66 mm iznad linije koja spaja tragus medialis i infraorbitalnu točku). Svaki ispitanik učinio je po tri kretnje protruzije, tri kretnje lijeve laterotruzije i tri kretnje desne laterotruzije. Softver uređaja izračunao je prosjek vrijednosti zadanih okluzijskih odrednica (kut nagiba kondilne staze, Bennettov kut) za individualizaciju odabranih dentalnih artikulatora za svakog ispitanika koje su se primijenile u ovom istraživanju $(22,23)$.

\section{Rezultati}

$\mathrm{U}$ istraživanju je sudjelovalo ukupno 30 asimptomatskih ispitanika raspodijeljenih prema spolu (15 žena i 15 muškaraca) s normalnom okluzijom (Angleova klasa I) te bez kliničkih znakova i simptoma temporomandibularnih poremećaja. Ispitanici su bili u dobi između 20 i 34 godine $(25,7 \pm 2,9$ godina). U tablici 1. nalaze se deskriptivna obilježja ispitivanih varijabli (vrijednosti lijevoga i desnoga kondilnog nagiba izmjerenog obavljanjem protruzijske kretnje donje čeljusti te lijevoga i desnoga Bennettova kuta izmjerenog izvođenjem desne i lijeve lateralne kretnje donje čeljusti) korištenjem dviju metoda (centrični/ekscentrični registrati i uređaj Arcus Digma) kako bi se programirala tri prilagodljiva artikulatorska sustava (SAM 3, Protar i Artex CR). Prosječne vrijednosti izmjerenih parametara za koje su korišteni voštani ekscentrični registrati pokazivale su veće vrijednosti (u rasponu od $5^{\circ}$ do $10^{\circ}$ ) u odnosu prema vrijednostima izmjerenima uređajem Arcus Digma.

Kolmogorov-Smirnovljev test pokazao je normalnu distribuciju za ispitivanje samih vrijednosti, pa su se u daljnjim postupcima primjenjivale metode parametrijske statističke raščlambe. Sve varijable testirane su Studentovim t-testom za nezavisne uzorke s obzirom na spol. Nisu pronađene statistički značajne razlike ni za jednu testiranu varijablu prema spolu $(\mathrm{p}>0,05)$ (tablica 2.).

T-testom za zavisne uzorke provjereni su parovi varijabli istovjetni po kretnji (izmjerenom kutu lijevoga i desnoga nagiba kondilne staze i Bennettovih kutova) i unutar jedne vrste artikulatora (SAM 3, Protar 7 i Artex CR), a s obzirom na primijenjenu metodu (voštani ekscentrični registrati i Arcus Digma). U tablici 3. prikazane su statistički značajne razlike na razini $\mathrm{p}<0,05$ za većinu testiranih varijabli, osim za varijable para 9 i 10 (lijevi i desni nagib kondilne staze - protruzijska kretnja donje čljusti za artikulator Artex CR). Razlike 
Table 1 Descriptive features of the left and right condylar path inclination/left and right Bennett angle for programming of adjustable articulator systems (SAM 3, Protar 7 and Artex CR) by means of wax centric/eccentric records and Arcus Digma device.

Tablica 1. Deskriptivna obilježja lijevog i desnog nagiba kondilne staze/lijevog i desnog Bennettova kuta za programiranje prilagodljivih artikulatorskih sustava (SAM 3, Protar 7 i Artex CR) s pomoću centričnih/ekscentričnih voštanih registrata i uređaja Arcus Digma

\section{Examined variables $\bullet$ Ispitivane varijable}

SAM 3 (wax record) - protrusion left $\bullet$ (voštani registrat) - protruzija lijevo

SAM 3 (wax record) - protrusion right $\bullet$ (voštani registrat) - protruzija desno

SAM 3 (wax record) - Bennett left $\bullet$ (voštani registrat) - Bennett. kut lijevo

SAM 3 (wax record) - Bennett right $\bullet$ (voštani registrat) - Bennett. kut desno

SAM 3 (Arcus Digma) - protrusion left $\bullet$ (Arcus Digma) - protruzija lijevo

SAM 3 (Arcus Digma) - protrusion right $\bullet$ (Arcus Digma) - protruzija desno

SAM 3 (Arcus Digma) - Bennett left • (Arcus Digma) - Bennett. kut lijevo

SAM 3 (Arcus Digma) - Bennett right • (Arcus Digma) - Bennett. kut desno

Protar (wax record) - protrusion left • (voštani registrat) - protruzija lijevo

Protar (wax record) - protrusion right $\bullet$ (voštani registrat) - protruzija desno

Protar (wax record) - Bennett left • (voštani registrat) - Bennett. kut lijevo

Protar (wax record) - Bennett right $\bullet$ (voštani registrat) - Bennett. kut desno

Protar (Arcus Digma) - protrusion left • (Arcus Digma) - protruzija lijevo

Protar (Arcus Digma) - protrusion right $\bullet$ (Arcus Digma) - protruzija desno

Protar (Arcus Digma) - Bennett left • (Arcus Digma) - Bennett. kut lijevo

Protar (Arcus Digma) - Bennett right • (Arcus Digma) - Bennett. kut desno

Artex CR (wax record) - protrusion left • (voštani registrat) - protruzija lijevo

Artex CR (wax record) - protrusion right $\bullet$ (voštani registrat) - protruzija desno

Artex CR (wax record) - Bennett left • (voštani registrat) -Bennett. kut lijevo

Artex CR (wax record) - Bennett right • (voštani registrat)-Bennett. kut desno

Artex CR (Arcus Digma) - protrusion left $\bullet$ (Arcus Digma) - protruzija lijevo

Artex CR (Arcus Digma) - protrusion right $\bullet$ (Arcus Digma) - protruzija desno

Artex CR (Arcus Digma) - Bennett left • (Arcus Digma) - Bennett. kut lijevo

Artex CR (Arcus Digma) - Bennett right $\bullet$ (Arcus Digma) - Bennett. kut desno

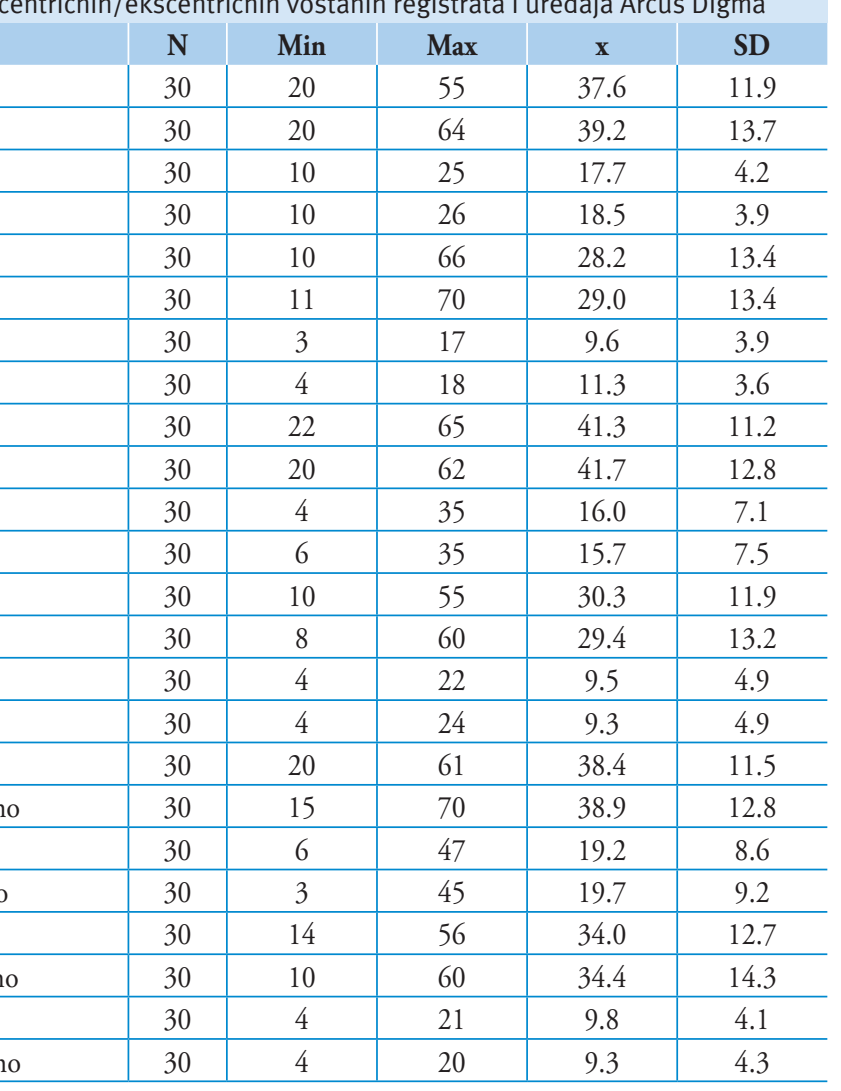

Table 2 Examined variables testing with respect to gender (t-test for independent samples).

Tablica 2. Testiranje ispitivanih varijabli s obzirom na spol (t-test za nezavisne uzorke

Examined variables $\bullet$ Ispitivane varijable

SAM 3 (wax record) - protrusion left • (voštani registrat) - protruzija lijevo

SAM 3 (wax record) - protrusion right $\bullet$ (voštani registrat) - protruzija desno

SAM 3 (wax record) - Bennett left $\bullet$ (voštani registrat) - Bennett. kut lijevo

SAM 3 (wax record) - Bennett right $\bullet$ (voštani registrat) - Bennett. kut desno

SAM 3 (Arcus Digma) - protrusion left $\bullet$ (Arcus Digma) - protruzija lijevo

SAM 3 (Arcus Digma) - protrusion right • (Arcus Digma) - protruzija desno

SAM 3 (Arcus Digma) - Bennett left • (Arcus Digma) - Bennett. kut lijevo

SAM 3 (Arcus Digma) - Bennett right • (Arcus Digma) - Bennett. kut desno

Protar (wax record) - protrusion left $\bullet$ (voštani registrat) - protruzija lijevo

Protar (wax record) - protrusion right $\bullet$ (voštani registrat) - protruzija desno

Protar (wax record) - Bennett left • (voštani registrat) - Bennett. kut lijevo

Protar (wax record) - Bennett right $\bullet$ (voštani registrat) - Bennett. kut desno

Protar (Arcus Digma) - protrusion left • (Arcus Digma) - protruzija lijevo

Protar (Arcus Digma) - protrusion right $\bullet$ (Arcus Digma) - protruzija desno

Protar (Arcus Digma) - Bennett left • (Arcus Digma) - Bennett. kut lijevo

Protar (Arcus Digma) - Bennett right • (Arcus Digma) - Bennett. kut desno

Artex CR (wax record) - protrusion left $\bullet$ (voštani registrat) - protruzija lijevo

Artex CR (wax record) - protrusion right $\bullet$ (voštani registrat) - protruzija desno

Artex CR (wax record) - Bennett left • (voštani registrat) -Bennett. kut lijevo

Artex CR (wax record) - Bennett right $\bullet$ (voštani registrat) - Bennett. kut desno

Artex CR (Arcus Digma) - protrusion left $\bullet$ (Arcus Digma) - protruzija lijevo

Artex CR (Arcus Digma) - protrusion right $\bullet$ (Arcus Digma) - protruzija desno

Artex CR (Arcus Digma) - Bennett left • (Arcus Digma) - Bennett. kut lijevo

Artex CR (Arcus Digma) - Bennett right $\bullet$ (Arcus Digma) - Bennett. kut desno

$\mathrm{df}-$ degrees of freedom $\bullet$ stupnjevi slobode, $\mathrm{P}-$ significance $\bullet$ značajnost.

t-test

\begin{tabular}{|c|c|}
\hline df & $P$ \\
\hline 28 & 0.655 \\
\hline 28 & 0.876 \\
\hline 28 & 0.228 \\
\hline 28 & 0.682 \\
\hline 28 & 0.219 \\
\hline 28 & 0.158 \\
\hline 28 & 0.226 \\
\hline 28 & 0.694 \\
\hline 28 & 0.169 \\
\hline 28 & 0.137 \\
\hline 28 & 0.468 \\
\hline 28 & 0.474 \\
\hline 28 & 0.387 \\
\hline 28 & 0.223 \\
\hline 28 & 0.387 \\
\hline 28 & 0.344 \\
\hline 28 & 0.687 \\
\hline 28 & 0.452 \\
\hline 28 & 0.150 \\
\hline 28 & 0.102 \\
\hline 28 & 0.658 \\
\hline 28 & 0.464 \\
\hline 28 & 0.219 \\
\hline 28 & 0.142 \\
\hline
\end{tabular}


of the arithmetic means show that the values measured with Arcus Digma are always lower, except for the variable pair 9 and 10 , in which, although the measured values are lower due to sample variance, their statistical significance cannot be proved. The highest statistical differences were found for the variable pair 3 and 4 (left and right Bennett angle for SAM 3 articulators).

Apart from the differences between the measured values of condylar path inclination and Bennett angle for each articulator, the purpose of this study was to test the mutual influence of the selected variables individually, combined and in total. Therefore, multivariate analysis of variance for dependent samples (MANOVA) was used. The variables were tested with respect to three parameters: articulator (SAM 3, Protar and Artex CR), measurement method (wax eccentric record and Arcus Digma) and measurement values (left and right condylar path inclination and Bennett angles). The effect of multivariate tests (Table 4) shows that there are statistically significant differences between each individual articulator $(p<0.001)$, measurement method ( $p<0.001)$, measured values of the articulator programming parameters $(p<0.001)$, in combination of articulator and measurement methods $(\mathrm{p}<0.012)$ and in total for articulator, measurement method and measured parameters $(\mathrm{p}<0.025)$. The combinations of articulator and measured parameters $(p<0.055)$ and measurement method and measured parameters $(p<0.590)$ showed no statistically significant differences. aritmetičkih sredina pokazuju da su vrijednosti dobivene Arcus Digmom uvijek manje, osim za par varijabli 9 i $10 \mathrm{kod}$ kojih se, iako su izmjerene vrijednosti manje zbog varijance uzorka, ne mogu dokazati sa statističkom značajnošću. Najveće statističke razlike uočene su za par varijabli 3 i 4 (lijevi i desni Bennettov kut za artikulatore SAM 3).

Osim razlika između izmjerenih vrijednosti nagiba kondilne staze i Bennettova kuta na pojedinom artikulatoru, svrha istraživanja bila je testirati uzajamni utjecaj odabranih varijabli pojedinačno, u kombinaciji i skupno. Za to je upotrijebljena multivarijatna analiza varijanca za zavisne uzorke (MANOVA). Kao što je poznato, varijable su testirane s obzirom na tri parametra - artikulator (SAM 3, Protar i Artex CR), metodu mjerenja (voštani ekscentrični registrat i Arcus Digma) i vrijednosti samog mjerenja (lijevi i desni nagib kondilne staze i Bennettovi kutovi). Efekt multivarijatnih testova (tablica 4.) pokazuje da postoje statistički značajne razlike između svakoga artikulatora $(p<0,001)$, metode mjerenja $(\mathrm{p}<0,001)$, izmjerenih vrijednosti parametara programiranja artikulatora $(\mathrm{p}<0,001)$, u kombinaciji artikulator i metoda mjerenja $(\mathrm{p}<0,012)$ te skupno artikulator, metoda mjerenja i izmjereni parametri $(\mathrm{p}<0,025)$. Kombinacije artikulator i izmjereni parametri $(\mathrm{p}<0,055)$ te metoda mjerenja i izmjereni parametri $(\mathrm{p},<, 0,590)$, ne pokazuju statistički značajne razlike.

\begin{tabular}{|c|c|c|c|c|c|}
\hline \multicolumn{6}{|c|}{$\begin{array}{l}\text { Table } 3 \text { Correspondence testing between two measurement methods (wax eccentric records and Arcus Digma) with respect to the measured } \\
\text { values of programming parameters (left and right condylar path inclination and Bennett angles) and dental articulator type (SAM } 3 \text {, } \\
\text { Protar and Artex CR) - t-test for dependent samples. } \\
\text { Tablica 3. Testiranje podudarnosti izmedu dviju metoda mjerenja (voštani ekscentrični registrati i Arcus digma) s obzirom na izmjerene } \\
\text { vrijednosti parametara programiranja (lijevi i desni nagib kondilne staze te Bennettovi kutovi) i tip dentalnog artikulatora (SAM } 3 \text {, } \\
\text { Protar i Artex CR) - t-test za zavisne uzorke. }\end{array}$} \\
\hline \multicolumn{2}{|r|}{$\begin{array}{c}95 \% \text { confidence interval } \bullet 95 \% \text { interval pouzdanosti } \\
\text { Upper } \bullet \text { Gornji }\end{array}$} & \multirow{2}{*}{$\begin{array}{c}\begin{array}{c}\text { Differences } \\
\text { Razlike }\end{array} \\
17.516\end{array}$} & \multirow{2}{*}{$\begin{array}{c}\mathbf{t} \\
2.851\end{array}$} & \multirow{2}{*}{$\begin{array}{l}\text { df } \\
29\end{array}$} & \multirow{2}{*}{$\begin{array}{c}P \\
.008\end{array}$} \\
\hline Pair $1 ・$ Par 1 & $\begin{array}{l}\text { Wax record SAM } 3 \text { - protrusion right / SAM } 3 \text { Arcus - protrusion right } \bullet \\
\text { Voštani registrat SAM } 3 \text { - protruzija desno / SAM } 3 \text { Arcus - protruzija desno }\end{array}$ & & & & \\
\hline Pair $2 \cdot \operatorname{Par} 2$ & $\begin{array}{l}\text { Wax record SAM } 3 \text { - protrusion left / SAM } 3 \text { Arcus - protrusion left } \bullet \\
\text { Voštani registrat SAM } 3 \text { - protruzija lijevo / SAM } 3 \text { Arcus - protruzija lijevo }\end{array}$ & 16.616 & 2.579 & 29 & .015 \\
\hline Pair $3 \cdot \operatorname{Par} 3$ & $\begin{array}{l}\text { Wax record SAM } 3 \text { - Bennett right / SAM } 3 \text { Arcus - Bennett right } \bullet \\
\text { Voštani registrat SAM } 3 \text { - Bennet desno / SAM } 3 \text { Arcus - Bennett desno }\end{array}$ & 9.263 & 2.579 & 29 & .000 \\
\hline Pair $4 \cdot \operatorname{Par} 4$ & $\begin{array}{l}\text { Wax record SAM } 3 \text { - Bennett left / SAM } 3 \text { Arcus - Bennett left } \bullet \\
\text { Voštani registrat SAM } 3 \text { - Bennett lijevo / SAM } 3 \text { Arcus - Bennett lijevo }\end{array}$ & 10.586 & 7.350 & 29 & .000 \\
\hline Pair $5 \bullet \operatorname{Par} 5$ & $\begin{array}{l}\text { Wax record Protar - protrusion right / Protar Arcus - protrusion right } \bullet \\
\text { Voštani registrat Protar - protruzija desno / Protar Arcus - protruzija desno }\end{array}$ & 18.232 & 3.752 & 29 & .001 \\
\hline Pair $6 \bullet \operatorname{Par} 6$ & $\begin{array}{l}\text { Wax record Protar - protrusion left / Protar Arcus - protrusion left } \bullet \\
\text { Voštani registrat Protar - protruzija lijevo / Protar Arcus - protruzija lijevo }\end{array}$ & 16.867 & 3.902 & 29 & .001 \\
\hline Pair $7 \bullet \operatorname{Par} 7$ & $\begin{array}{l}\text { Wax record Protar - Bennett right / Protar Arcus - Bennett right } \bullet \\
\text { Voštani registrat Protar - Bennet desno / Protar Arcus - Bennett desno }\end{array}$ & 9.917 & 3.668 & 29 & .001 \\
\hline Pair $8 \bullet \operatorname{Par} 8$ & $\begin{array}{l}\text { Wax record Protar - Bennett left / Protar Arcus - Bennett left } \bullet \\
\text { Voštani registrat Protar - Bennett lijevo / Protar Arcus - Bennett lijevo }\end{array}$ & 10.058 & 3.791 & 29 & .001 \\
\hline Paiir $9 \bullet$ Par 9 & $\begin{array}{l}\text { Wax record Artex CR - protrusion right / Artex CR Arcus - protrusion right } \bullet \\
\text { Voštani registrat Artex CR - protruzija desno / Artex CR Arcus - protruzija desno }\end{array}$ & 11.000 & 1.452 & 29 & .157 \\
\hline $\begin{array}{l}\text { Pair } 10 \bullet \\
\text { Par } 10\end{array}$ & $\begin{array}{l}\text { Wax record Artex CR - protrusion left / Artex CR Arcus - protrusion left } \bullet \text { Voštani } \\
\text { registrat Artex CR - protruzija lijevo / Artex CR Arcus - protruzija lijevo }\end{array}$ & 10.601 & 1.414 & 29 & .168 \\
\hline $\begin{array}{l}\text { Pair 11• } \\
\text { Par } 11\end{array}$ & $\begin{array}{l}\text { Wax record Artex CR - Bennett right / Artex CR Arcus - Bennett right } \bullet \\
\text { Voštani registrat Artex CR - Bennet desno / Artex CR Arcus - Bennett desno }\end{array}$ & 13.546 & 6.578 & 29 & .000 \\
\hline $\begin{array}{l}\text { Pair } 12 \bullet \\
\text { Par } 12\end{array}$ & $\begin{array}{l}\text { Wax record Artex CR - Bennett left / Artex CR Arcus - Bennett left } \bullet \\
\text { Voštani registrat Artex CR - Bennett lijevo / Artex CR Arcus - Bennett lijevo }\end{array}$ & 12.311 & 6.410 & 29 & .000 \\
\hline
\end{tabular}




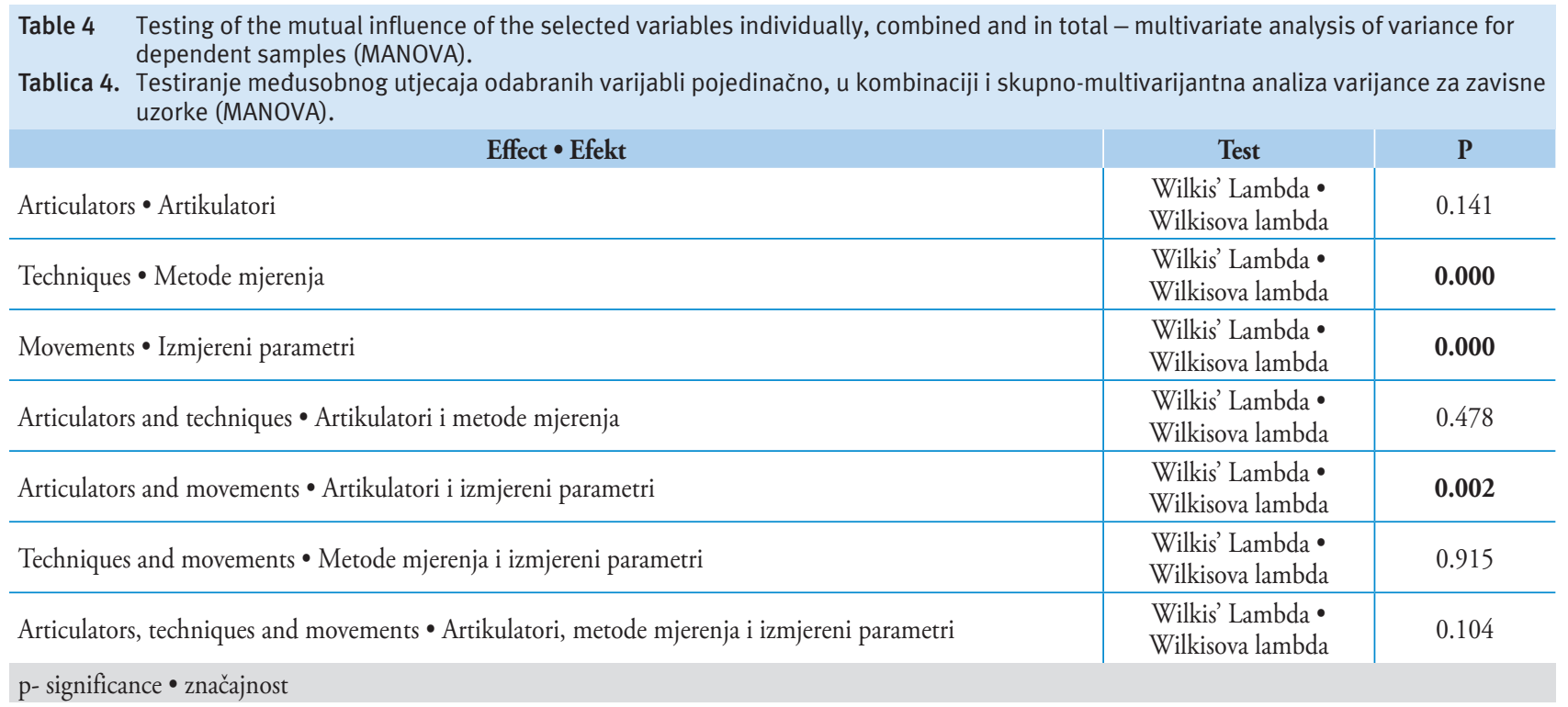

\section{Discussion}

The average values of the left and right condylar path inclination and the right and left Bennett angle showed a tendency toward higher values using the method of wax eccentric records rather than those using the method with Arcus Digma device for all the three articulator systems used in this study (Table 1). However, the average values for condylar path inclination, considering the type of occlusion (Angle class I) amounted to $34^{\circ}-41.7^{\circ}$ for wax eccentric records and $28.2^{\circ}-34.4^{\circ}$ for Arcus Digma device. Bennett angles amounted to $15.7^{\circ}-19.7^{\circ}$ for wax eccentric records and $9.3^{\circ}$ $9.8^{\circ}$ for Arcus Digma. In this study, no statistically significant differences for the tested variables were found according to gender (Table 2), which could have been expected with respect to the selected sample and its age limit. A review of the literature on the average values of condylar path inclination have showed large variations, which, as it can commonly be explained, arose from different study sample sizes, different measurement methods for the condylar inclination according to different referential planes $(12,24,25)$. With respect to the measured average values of Bennett angle, probably the best study to compare is the study by a group of Croatian authors (14), who measured the average Bennett angle of $7.7^{\circ}$ in their test group (Arcus Digma device used). It should be noted that the same angle was measured for subjects with Angle class I, but also other subjects with other Angle classes had the same average value of Bennett angle. Average Bennett angle of $7^{\circ}$ to $8^{\circ}$ was also found in other studies $(26,27)$, whereby its value of $15^{\circ}$, which is most often recommended for average articulator programming, represents a higher value of Bennett angle than the value in most individuals. Hobo et al. (28) argue that in average adjustable articulator programming, where a higher condylar path inclination and a smaller Bennett angle are used, the incidence of interference in excursive movements of the articulator can be increased. Since dental articulators are already widely used in everyday practice, this suggests that they should be individually set/ programmed.

\section{Rasprava}

Prosječne vrijednosti lijevoga i desnoga nagiba kondilne staze te lijevoga i desnoga Bennettova kuta pokazale su tendenciju većih vrijednosti pri primjeni metode voštanih ekscentričnih registrata negoli metode tijekom koje se koristio uređaj Arcus Digma za sva tri artikulatorska sustava upotrijebljena u ovom istraživanju (tablica 1.). No prosječne vrijednosti za nagib kondilne staze, s obzirom na vrstu okluzije (Angleovu klasu I), iznosile su od $34^{\circ}$ do $41,7^{\circ}$ za voštane ekscentrične registrate i od $28,2^{\circ}$ do $34,4^{\circ}$ za uređaj Arcus Digma. Bennettovi kutovi iznosili su od $15,7^{\circ}$ do $19,7^{\circ}$ za voštane ekscentrične registrate i od $9,3^{\circ}$ do $9,8^{\circ}$ za Arcus Digmu. U ovoj studiji nisu nađene statistički značajne razlike za ispitivane varijable prema spolu (tablica 2.), što se moglo očekivati s obzirom na odabrani uzorak i njegovu dobnu granicu. Pregledom literature o vrijednostima nagiba kondilne staze, uočene su velike varijacije u prosječnim vrijednostima koje se najčšćce objašnjavaju različitim veličinama uzoraka istraživanja, različitim metodama mjerenja navedenog nagiba i određivanjem nagiba prema različitim referentnim ravninama $(12,24,25)$. Glede izmjerenih prosječnih vrijednosti Bennettova kuta, možda je najbolja studija za usporedbu autora (14) iz Hrvatske koji su u svojoj ispitnoj skupini izmjerili prosječan Bennettov kut od 7,70 (korišsten uređaj Arcus Digma). Treba istaknuti da su isti kut izmjerili za ispitanike s Angleovom klasom I, ali i ostali s drugim Angleovim klasama imali su istu vrijednost prosječnoga Bennettova kuta. Prosječni Bennettov kut od $7^{\circ}$ do $8^{\circ}$ zabilježen je i u drugim studijama $(26,27)$, pa vrijednost od $15^{\circ}$ koja se najčešce preporučuje za prosječno programiranje artikulatora znači veću vrijednost Bennettova kuta od onih nađenih kod većine pojedinaca. Hobo i suradnici (28) ističu da je pri prosječnom programiranju prilagodljivih artikulatora, kada je određen veći nagib kondilne staze i manji Bennettov kut, veća mogućnost interferencija u ekskurzijskim kretnjama artikulatora. Time sugeriraju da, kad se već rabe dentalni artikulatori u svakodnevnoj praksi, treba težiti njihovu individualiziranom namještanju/programiranju.

Ratzman i suradnici (29) uspoređivali su prosječne vrijednosti horizontalnog nagiba kondila zabilježenog protru- 
Ratzman et al. (29) compared the average values of horizontal condylar inclination recorded by means of protrusive interocclusal record and electronic pantograph on a sample of 23 subjects divided by gender. Statistical analysis found a match between these two methods, but it was insufficient in order to be reliably used for dental articulator programming in clinical conditions. The values of condylar path inclination obtained based on protrusive eccentric record, showed a high variance in relation to the values obtained with electronic pantograph. In conclusion, they recommend using a pantograph in relation to protrusive records with the aim of individualized adjustable dental articulator programming.

The results of this study indicate similar tendencies, i.e. statistically significant differences between the measured parameters were found, caused by the influence of different constructions of the dental articulators used in the study (SAM 3, Protar 7 and Artex CR), as well as the measurement method (wax eccentric record and Arcus Digma) (Table 3 and 4). The reason for this may be explained by the fact that wax records relate only to the initial part of protrusive/ lateral movement, while in case of Arcus Digma application, TMJ condyles perform movements throughout their range. Angles emerging during these condylar movements form angles that in the application of wax centric records (especially in Bennett lateral movement) have higher values than measured with Arcus Digma device. A recent study by Ćimić et al. (12) points to the fact that condylar movement in the sagittal direction (which happens during protrusive mandibular movement) is not uniform; indeed, there was a difference between the left and right side of the measured condylar inclination, amounting to over $10^{\circ}$. Their measurements were carried out with Arcus Digma device, and the test group was almost identical as in this study. It included younger subjects with normal occlusion. Another reason could be unequal hinge axis transfer to the selected dental articulators using anatomic (wax centric record) and kinematic face bow (Arcus Digma device). Although for both arches in this study an average hinge axis transfer was used, and not kinematic axis, it should be noted that some articulator systems, especially their anatomic face bows are oriented (placed) on the subject according to different reference planes (e.g. for SAM articulators according to axial-orbital plane, and for Protar articulators according to the Camper's plane). It is known that reference planes are not parallel to each other (differences range on average $10^{\circ}$ to $\left.15^{\circ}\right)$. Otherwise, in the scientific literature, the position of the terminal hinge axis is under argument. The prevailing view is that this axis is determined by two points situated in the canter of joint heads of mandibular ramus. However, some authors believe that it is located in the mandibular ramus or even outside of it (8).

\section{Conclusion}

Based on the results of this study, in younger subjects with normal occlusion (Angle class I), the average values of condylar paths inclination and Bennett angle differed between the two methods used (wax eccentric record and Arcus Digma device) in the same way as parameters necessary for adjust- zijskim interokluzalnim registratom i elektroničkim pantografskim uređajem na uzorku od 23 ispitanika raspodijeljenih prema spolu. Statističkom analizom zaključili su da je bilo podudaranja između tih dviju metoda, ali nedovoljnog da bi se u kliničkim okolnostima mogla pouzdano koristiti za programiranje dentalnih artikulatora. Vrijednosti nagiba kondilne staze, dobivene na temelju protruzijskog ekscentričnog registrata, pokazivale su veliku varijancu u odnosu prema vrijednostima dobivenima elektroničkim pantografskim uređajem. Zaključno, preporučuju upotrebu pantografskog uređaja u usporedbi s protruzijskim registratima u svrhu individualiziranog programiranja prilagodljivih dentalnih artikulatora. Rezultati ove studije pokazuju slične tendencije, tj. zabilježene su statistički značajne razlike između izmjerenih parametara nastale zbog utjecaja različitih konstrukcija dentalnih artikulatora korištenih u istraživanju (SAM 3, Protar 7 i Artex CR) te metode mjerenja (voštani ekscentrični registrati i Arcus Digma) (tablice 3. i 4.). Razlog za to može biti u činjenici da se voštanim registratima bilježi samo početni dio protruzijske i lateralne kretnje, a u slučaju upotrebe uređaja Arcus Digma, kondili čeljusnih zglobova obavljaju kretnje u cijelom svojem opsegu. Kutovi koji nastaju tijekom tih kretnji kondila oblikuju kutove koji pri primjeni voštanih centričnih registrata (posebno kod Bennetove lateralne kretnje) imaju veće vrijednosti u odnosu prema uređaju Arcus Digma. Novija studija Ćimića i suradnika (12) upućuje na činjenicu da kretnja kondila u sagitalnom smjeru (koja se događa tijekom protruzijske kretnje donje čeljusti) nije uniformna, dapače, postojala je razlika između lijeve i desne strane izmjerenog kondilnog nagiba koja je iznosila i više od $10^{\circ}$. Mjerenja su obavljena uređajem Arcus Digma, a ispitna skupina bila je gotovo istovjetna kao u ovom istraživanju - mlađi ispitanici s normalnom okluzijom. Drugi razlog mogao bi biti nejednak prijenos šarnirske osi s pomoću anatomskog (voštani centrični registrat) i kinematskog obraznog luka (uređaj Arcus Digma) u odabranim dentalnim artikulatorima. Iako su se oba luka o ovom istraživanju koristila prijenosom prosječne šarnirske osi, a ne kinematske osi, ipak treba istaknuti da se pojedini artikulatorski sustavi, odnosno njihovi anatomski obrazni lukovi orijentiraju (postavljaju) na ispitaniku prema različitim referentnim ravninama (npr. za artikulatore SAM prema osno-orbitalnoj ravnini, a za artikulatore Protar prema Camperovoj ravnini). Poznata je činjenica da referentne ravnine nisu uzajamno paralelne (razlike su u prosjeku $10^{\circ}$ do $15^{\circ}$ ). Inače, u znanstvenoj je literaturi dvojbena pozicija terminalne šarnirske osi. Prevladava stajalište da tu os određuju dvije točke smještene u središtu zglobnih glavica uzlaznih krakova donje čeljusti. No određeni autori smatraju da se tu ne nalazi, nego je smještena u uzlaznom kraku donje čeljusti ili čak izvan njega (8).

\section{Zaključak}

$\mathrm{Na}$ temelju rezultata dobivenih u ovoj studiji, kod mladih ispitanika s normalnom okluzijom (Angleova klasa I), prosječne vrijednosti nagiba kondilne staze i Bennettova kuta razlikovale su se između dviju korištenih metoda (voštani ekscentrični registrati i uređaj Arcus Digma) kao parametara prijeko 
able dental articulator programming. When using multivariate analysis of variance for dependent samples (MANOVA), the average values of the measured parameters are influenced by articulator selection (design) and measurement method, which was confirmed by statistical significance found between the tested variables. The results obtained by using Arcus Digma device corresponded to the data from the scientific literature to a higher extent. This favors Arcus Digma device as a more reliable method for determination of condylar path inclination and Bennett angle, and thus can be considered more valid for individualized dental articulator programming.

\section{Acknowledgements}

Each subject signed their informed consent to voluntarily participate in the study approved by the Ethics Committee of the School of Dental Medicine, University of Zagreb, Croatia.

We would like to thank Assistant Professor Davor Illeš, $\mathrm{PhD}$, for the help in carrying out statistical analysis of the data in this study.

\section{Conflict of interest}

The authors report no conflict of interest. potrebnih za programiranje prilagodljivih dentalnih artikulatora. Multivarijatnom analizom varijance za zavisne uzorke (MANOVA) na prosječne vrijednosti izmjerenih parametara djeluje odabir (dizajn) artikulatora i metoda mjerenja, što je potvrđeno statističkom značajnošću pronađenom između testiranih varijabli. Rezultati izmjerenih parametara s pomoću uređaja Arcus Digma bili su više u skladu s podatcima iz znanstvene literature. To daje prednost uređaju Arcus Digma kao pouzdanijoj metodi za određivanje nagiba kondilne staze i Bennettova kuta, pa se može smatrati prikladnijom za individualizirano programiranje prilagodljivih dentalnih artikulatora.

\section{Zahvale}

Svaki ispitanik potpisao je informirani pristanak da dragovoljno sudjeluje u istraživanju koje je odobrilo Etičko povjerenstvo Stomatološkog fakulteta Sveučilišta u Zagrebu, Hrvatska. Zahvaljujemo doc. dr. sc. Davoru Illešu na pomoći u obavljanju statističke analize u ovoj studiji.

\section{Sukob interesa}

Autori izjavljuju da nisu bili u sukobu interesa.

\section{Sažetak}

Svrha istraživanja: Programiranje zglobnih mehanizama/parametara (kondilni nagib staze i Bennettov kut) prilagodljivih dentalnih artikulatora preduvjet je za obavljanje položaja i kretnji donje čeljusti. Svrha istraživanja bila je ispitati značajne razlike između dviju metoda (voštani ekscentrični registrati i uređaj Arcus Digma) mjerenjem tih zglobnih parametara upotrebom triju različitih dentalnih artikulatora (SAM 3, Protar 7 i Artex CR). Materijal i metode: $U$ istraživanju je sudjelovalo 30 asimptomatskih mlađih ispitanika - studenata Stomatološkog fakulteta (u dobi $25,7 \pm 2,9$ godina), bili su podijeljeni prema spolu i imali su normalnu okluziju (Angleova klasa I). Nakon uzimanja anatomskih otisaka obaju zubnih lukova, za svakog ispitanika izliveni su radni modeli u tvrdoj sadri. Vrijednosti lijevoga i desnog sagitalnog nagiba kondila i Bennettova kuta, s pomoću dviju metoda voštanih ekscentričnih protruzivnih i lateralnih registrata te uređaja Arcus Digma, bili su izmjereni u svrhu programiranja već spomenutih zglobnih parametara u trima različitim sustavima artikulatora. Rezultati: Prosječne vrijednosti izmjerenih parametara kondilnoga nagiba staze i Bennettova kuta voštanih ekscentričnih registrata bile su više (u prosjeku za $5^{\circ}$ do $10^{\circ}$ ) u odnosu prema vrijednostima izmjerenima uređajem Arcus Digma. Statistički značajne razlike nađene između izmjerenih zglobnih parametara $(p<0,025)$ bile su pod utjecajem dizajna artikulatora i metoda mjerenja (t-test za zavisne uzorke i MANOVA test). Zaključak: Upotreba uređaja Arcus Digma može se smatrati znatno pouzdanijom i prikladnijom metodom za individualizirano programiranje dentalnih artikulatora u usporedbi s metodom voštanih ekscentričnih registrata.
Zaprimljen: 14. travnja 2019.

Prihvaćen: 25. lipnja 2019.

Adresa za dopisivanje

izv. prof. dr. sci. Robert Ćelić

Stomatološki fakultet

Sveučilište u Zagrebu

Zavod za mobilnu protetiku

Ivana Gundulića 5, 10000 Zagreb,

Hrvatska

tel: 0038514802118

celic@sfzg.hr

Ključne riječi

temporomandibularni zglob; zubna okluzija; zubni artikulatori

\section{References}

1. Knezović-Zlatarić D, Ćelić R, Kovačić I, Krstulović L. Setting Procedure of the Fully Adjustable SAM 3 Articulator. Acta Stomat Croat. 2003;37:275-86.

2. Ingervall B. Range of sagittal movement of the mandibular condyles and inclination of the condyle path in children and adults. Acta Odontol Scand. 1972 Mar;30(1):67-87.

3. Tsiklakis K, Syriopoulos K, Stamatakis HC. Joint radiographic examination of the temporomandibular using cone beam computed tomography. Dentomaxillofac Radiol. 2004 May;33(3):196-201.

4. Sakar O, Calisir F, Oztas E, Marsan G. Evaluation of the effects of temporomandibular joint disk displacement and its progression on dentocraniofacial morphology in symptomatic patients using lateral cephalometric analysis. Cranio. 2011 Jul;29(3):211-8.

5. Žabarović D, Jerolimov V, Carek V, Vojvodić D, Žabarović K, Buković D Jr. The effect of tooth loss on the TM-joint articular eminence inclination. Coll Antropol. 2000 Jul;24 Suppl 1:37-42.

6. Jasinevicius TR, Pyle MA, Lalumandier JA, Nelson S, Kohrs KJ, Turp $\mathrm{JC}$, et al. Asymmetry of the articular eminence in dentate and partially edentulous populations. Cranio. 2006 Apr;24(2):85-94.
7. Katsavrias EG. Changes in articular eminence inclination during the craniofacial growth period. Angle Orthod. 2002 Jun;72(3):25864.

8. Bumann A, Lotzmann U. TMJ Disorders and Orofacial Pain. The Role of Dentistry in a Multidisciplinary Diagnostic Approach. Stuttgart, Thieme, 2002.

9. Papini A. Gli articolatori limiti e indicazioni. Milano, Quintessenza, 2012.

10. Kraljević K. Anatomija i fiziologija okluzije. Zagreb: Globus; 1991.

11. The glossary of the prosthodontics terms. J Prosthet Dent. 2017 May;117(5S):e1-e105.

12. Ćimić S, Kraljević Šimunković S, Badel T, Dulčić N, Alajbeg I, Ćatić A. Measurements of the sagittal condylar inclination: intraindividual variations. Cranio. 2014 Apr;32(2):104-9.

13. Ćimić S, Šimunković SK, Simonić Kocijan S, Matijević J, Dulčić N, Ćatić A. Articulator-related registration and analysis of sagittal condylar inclination. Acta Clin Croat. 2015 Dec;54(4):432-7.

14. Ćimić S, Kraljević Šimunković S, Ćatić A. The relationship between a patient's Angle type of occlusion and recorded Bennett angle values. J Prosthet Dent. 2016 Jun;115(6):729-35. 
15. Koolstra JH. Dynamics of the human masticatory system. Crit Rev Oral Biol Med. 2002; 13: 366-76.

16. Stiesch-Scholz M, Demling A. Rossbach Reproducibility of joint movements in patients with craniomandibular disorders. J Oral Rehabil. 2006;33:807-12.

17. Prasad KD, Shetty M, Chandy BK. Evaluation of condylar inclination of dentulous subjects determined by axiograph and to compare with manual programming of articulators using protrusive interocclusal record. Contemp Clin Dent. 2015 Jul-Sep;6(3):371-4.

18. Pröschel P, Morneburg T, Hugger A, Kordass B, Ottl P, Niedermeier W, Wichmann M. Articulator-related registration - a simple concept for minimizing eccentric occlusal errors in the articulator. Int J Prosthodont. 2002 May-Jun;15(3):289-94.

19. Fanucci E, Spera E, Ottria L, Barlattani A Jr, Fusco N, Mylonakou I, Broccoli P, Barlattani A, Simonetti. Bennett movement of mandible: a comparison between traditional methods and a 64-slices CT scanner. Oral Implantol (Rome). 2008 Apr;1(1):15-20.

20. Čimić S, Kraljević Šimunković S, Savić Mlakar A, Simonić Kocijan $S$, Tariba $P$, Catić $A$. Ponovljivost određivanja centrične relacije kod pacijenata s dislokacijom diska s redukcijom. Acta Stomat Croat. 2018;52:24-31.

21. KaVo Dental Excellence. Instructions for use ARCUS digma USB, SD, wireless. Biberach, Zerbris medical, 2008.

22. Obrež, A; Gallo, LM. Anatomy and function of the TMJ. In: Laskin, DM - editor. TMDs: an evidence-based approach to diagnosis and treatment. Hannover: Quintessence; 2006. p. 39-41.
23. Reiber T, Dickbertel J. Zur Lage der Scharnierachsenpunkte. Dtsch Zahnarztl Z. 1988;43: 194-8

24. Reicheneder C, Gedrange T, Baumert U, Faltermeier A, Proff P. Variations in the inclination of the condylar path in children and adults. Angle Orthod. 2009;79:958-63.

25. Reicheneder C, Proff P, Baumert U, Gedrange T. Comparison of maximum mouth-opening capacity and condylar path length in adults and children during the growth period. Ann Anat. 2008;190(4):344-50.

26. Hernandez AI, Jasinevicius TR, Kaleinikova Z, Sadan A. Symmetry of horizontal and sagittal condylar path angles: an in vivo study. Cranio. 2010 Jan;28(1):60-6.

27. Canning T, O'Connell BC, Houston F, O'Sullivan M. The effect of skeletal pattern on determining articular settings for prosthodontic rehabilitation: an in vivo study. Int J Prosthodont. 2011 JanFeb;24(1):16-25.

28. Hobo S, Schillingburg HT Jr, Whitsett LD. Articulator selection for restorative dentistry. J Prosthet Dent. 1976 Jul;36(1):35-43.

29. Ratzmann A, Mundt T, Schwahn C, Langhorth G, Hutzen D, Gedrange $T$, Kordass B. Comparative clinical investigation of horizontal condylar inclination using the JMA electronic recording system and a protrusive wax record for setting articulators. Int J Comput Dent. 2007 Jul;10(3):265-84. 